\title{
Bugis Adaptation Strategies in Karimunjawa Overseas Land
}

\author{
Titiek Suliyati ${ }^{1^{*}}$ \\ \{suliyati.titiek@gmail.com\} \\ 1*Departement of History, Faculty of Humanities, Dipnegoro University \\ Jl.Prof.H.Soedarto, SH.Tembalang Semarang
}

\begin{abstract}
This article is the research result of Bugis life in Karimunjawa. Buginese or Bugis is one of the tribes in Indonesia with great enthusiasm to migrate. This study aims to examine the reasons why the Bugis migrate to Karimunjawa, the reasons they settle, the adaptation strategies they use to survive in Karimunjawa and the social changes in their lives. The used method in this study was a qualitative method, with the data collection through literature studies, intensively observation by observing community activities accompanied by detailed records, and structured or unstructured in-depth interview. The results showed that Masompe ' (wander off) meant as a high prestige for the Bugis. The philosophy of Tellu Cappa ("three tips") is the capital of the Bugis to migrate. The adaptation that has been done by the Bugis tribe brings changes to the Bugis environment and the surrounding community, so as to create harmony in interaction.
\end{abstract}

Keywords: Strategies, adaptation, Bugis, Karimunjawa.

\section{Introduction}

One of the tribes in Indonesia with a tendency to migrate is Bugis tribe. Further, related to this migration activity, Bugis recognize the term sompe ', meaning migration land and pasompe' meaning nomads. Moreover, from several studies known that Bugis are actually not a group of people whose life is exploring the ocean, but farmers. This is in accordance with fertile South Sulawesi land and suitable for agricultural area. Bugis people development from farmers to maritime took place around the $18^{\text {th }}$ century [1].

The Bugis migration activity to all areas of Indonesia began since Makassar was ruled by the Dutch Colonial Government on 1667. Then the Dutch Colonial Government limited Bugis trade activities causing many Bugis travelled accross the sea to find new life resources to other regions throughout Indonesia and abroad [2]. In line with the statement by Lineton, pasompe' spirit 'is based on the character of Bugis who highly integrate freedom and honor. The freedom that is always fought by Bugis is the freedom of expressing opinions, seeking life resources and strive, and living. If they do not obtain one of those freedoms, they chose to move to a place that do not limit their freedom [3].

Sompe' initially it is a trading activity of Bugis to various regions of Indonesia even to foreign countries [4]. In the following decades, the spirit of migrating is also driven by the expectation of earning more income in work, trading, and achieving their education dream.

As pasompe' (nomads) Bugis armed with Tellu Cappa. Tellu Cappa (tellu means three, cappa means tip) is a passed down philosophy by Bugis ancestors and is very useful in their migration life, they are cappa 'lilae (tongue's tip), cappa' orowanewe (penis' tip), cappa 'kawalie (weapons/Badik). Cappa 'lilae as an allegory of speaking, communicating, and diplomatic skills associated with their daily activities.

Cappa 'orowanewe is a metaphor for Bugis men who nomads, who are expected to be able to marry noble women from the upper classes for instance the daughters of local rulers. 
While, Cappa 'kawalie is a metaphor for defense or self-defense for Bugis nomads who get insults or lowered their dignity. It is expected that Cappa 'Kawalie is not used frequently or as a last weapon if cappa lilae and cappa orowanewe do not work [5].

There had not been found the data of Bugis' sompe' activities to Karimunjawa. As the evidence that pasompe' has existed from long time ago, there is a Bugis village with typical Bugis characteristics in Kemojan village Karimunjawa. The Bugis live harmoniously and with the local people. This state indicates that Bugis can adapt well.

The research problem in this article is how the Bugis adopt the strategy adaptation on surrounding nature and environment. In addition, through the adaptation strategies perspective, this research is expected to be able to indicated the occuring changes in Bugis nomads to unite and become part of Kemojan Village community, and indicates their persistence in maintaining Bugis' identity at once.

\section{Research Method}

The used research method was descriptive qualitative. It was aimed to understand the phenomena experienced by research subject as a whole, related to behavior, perception, motivation, action, etc., described in words and sentences descriptively [6].

Data collection was performed by literature review, observation, and in-depth interviews [7]. A literature review was required to explain the obtained data and compare the writing in the literature with the studied problems [7]. Through literature review, the information about Bugis-Makssar culture was found, as well as their migration history throughout Indonesia included Karimunjawa. Besides using books, this research also used data from the internet. Furtheremore, the informants determination process was conducted by snow ball method, that was, choosen by the advice and information from the first informant and so on. The observation was conducted in Batulawang, Kemojan village, Karimunjawa. It was performed during cultural activities and in-depth interview [8]. Through in-depth interview, we could collect the data regrading their arrival, the reasons encouraging them to stay, how to adapt to the new environment, and what traditions have changed maintained. Through various methods of data collection, it was expected that there was sufficient data and analyzed through 3 (three) stages, namely: 1) data reduction; 2) display data, and conclusions, indicated by an analysis result description [8].

\section{Bugis Tribe's Pasompe' in Karimunjawa}

Further, There are no historical sources and written evidences of Bugis tribe to Karimunjawa and settled in several areas. The information regarding the existence of Bugis tribe in Karimunjawa, mainly Kemojan Village was obtained through oral history interview with several community leaders and several predecessor descendants who have understood the information about their ancestors history in Kemojan Village.

From some literatures, it is known that in the XV century Bugis has migrated from their original place to various places in the archipelago. This migration was conducted at that time to save their live from an inter-conflict in South Sulawesi causing an unsafe situation for Bugis people. In addition, the urge to seek a more comfortable life was also the reason for Bugis to migrate [9]. A source informs that Bugis are sailed to Karimunjawa islands in the $17^{\text {th }}$ and $18^{\text {th }}$ centuries [10]. This information cannot be fully trusted because there is no supporting data that is able to provide an adequate explanation. 
At the beginning of the journey, Bugis did not know about Karimunjawa, because this island was not the main destination. Their journey initially went to the Masalembo island, which was the area of East Java. Unfortunately, they found that the island was already crowded and there was no vacant land for them. From the fellow Bugis migrants information, they found that there was a large space for settlements, that was Karimunjawa Island, so, many Bugis sailed to Karimunjawa. Karimunjawa is considered a suitable place to settle and find new life resources, because, it does not have too many inhabitants, it has a calm nature and gives hope for a decent livelihood (Interview with Rusingi, March 2, 2019).

In Karimunjawa, Bugis are spread on several islands such as Parang, Genting, Nyamuk, and Kemojan Village. The largest number of Bugis people is in Kemojan Village. From several interviews with Bugis community leaders in Kemojan Village, it was obtained that the first Bugis arrived in Karimunjawa and lived at Kemojan Village was Leindra. It was estimated that the beginning of Bugis arrival in kemojan in 1930, marked by the event of "Babat Alas" performed by Leindra. The following years Bugis tribe led by Garusang arrived, followed by Ali Caco. The Bugis in Kemojan today is the fourth generation of Bugis figures' descendants above. After the arrival of Bugis in kemojan, the forests and bushes are opened into residential, agricultural, and plantation lands (Interview with Abdullah and Dupadu, March 3, 2019).

In general, Bugis people in Karimunjawa can live harmoniously with other tribes such as Javanese, Mandarese, and Madurese. The Bugis community still adheres to the life philosophy taught by their ancestors, "When in Rome, do as the Romans do". The meaning is Bugis people must be able to adjust to their environment and the local community. However, this philosophy is applied by the majority of Bugis people, so, their environmental adaptation is very easy for them (Interview with Abbas, March 4, 2019).

The Bugis adaptation of to the new environment harmoniously is also based on other characteristics taught by their parents, they are:

a. Sipakatau, appreciation to others. it is emphasizing good behavior on fellow human beings.

b. Sipakalebi, the attitude to give appreciation to other's greatness, for instance giving praise and pleasing others.

c. Sipakainge, the open attitude to provide constructive input or criticism on other people as well as on himself/herself [11].

Although Bugis people in Kemojan Village always maintain a harmonious life with the community in a new place, they do not keep quiet if the people in their new environment demean them. Moreover, the problems that are triggering disharmony among the communities are usually related to siri. For the Bugis siri is their soul, self-esteem, and dignity [12].

\section{Bugis Adaptation Strategies in Overseas.}

Adaptation is a process of self-adjustment by living things to survive in a new environment. The efforts by humans to survive in the new environment are natural and cultural processes, so, they will be accepted and become part of that environment. Adaptation is requirted because this new environment is different from their origin place, for instance differences in the natural, social, and cultural environments [13].

Bugis tribes on overseas land can apply three important issues, that are knowledge, awareness and ability [14]. The knowledge possessed by Bugis migrants in Kemojan village Karimunjawa, made them aware that migrants must know themselves on overseas lands. They must be able to adapt themselves to different cultural environments, so, they are integrated 
with the local community. Bugis migrants have a good awareness, so, they can place themselves and live in harmony with the local community without any disputes. Bugis migrants are able to understand and respect the local community culture and habits. This practice was balanced by introducing Bugis culture to the local community, such as language, food, the way of buidling Bugis houses, marriage traditions, birth tradition, and so on.

More important in Bugis adaptation strategy in Kemojan village, is the application of Tellu Cappa philosophy, which is very effective in adaptation process. Cappa lilae is applied in polite communication according to manners, mutual respect in their daily activities. Cappa 'orowanewe (penis tip) is conducted (in the ideal way) by marrying local rulers' daughter. In reality, if the idealized objectives are not achieved, many Bugis people marry local women from ordinary classes, both from local tribes and other tribes. Cappa 'kawalie (weapons/badik) can be said to be avoided most by Bugis in Kemojan. The Bugis will not use cappa 'kawalie if there is no hurtful excuse, degrading their self-esteem and dignity (Interview with Sakim, March 4 Maret 2019).

During their life in Kemojan, Bugis still retain some of their cultures, so, they do not lose their identity and cultural character. Bugis language is one of the characteristics maintained by Bugis in Kemojan. Bugis language is not only used by Bugis to communicate everyday, but also used by other tribes such as Javanese and Madurese. Among these three tribes, they understand each other's languages.

Bugis houses are maintained cultural feature on overseas lands by Bugis tribe. Even though not all Bugis people make Bugis houses, there are around 100 well maintained Bugis houses, so, when we enter the Kemojan area, we immediately understand this village is a Bugis village. Although, Bugis house in Kemojan is different from the original Bugis house in South Sulawesi proven by the lower pillars of Bugis house in Kemojan, but there are still distinctive features indicating Bugis houses characteristics. Bugis tribe try to introduce Bugis culture through tourism activities, by building cottages or a Home stay with a Bugis house model.

Bugis marriage in Kemojan, Batulawang, follows Javanese marriage rules and based on Islam. In the wedding ceremony, there are typical Bugis foods, including Bingkat, Bolu Pecak, Sarikaya. (Interview with Rosma, March 4, 2019). Moreover, In Bugis marriage system in Kemojan, known a Dower called Sompak. This money is given to the bride. Besides dower, when going to get married, the bridegroom gives dower to the bride's parents used for the wedding expenses. The stages in traditional Bugis marriages called Mattiro, is becoming a guest to get acquainted with the prospective bride and groom's family, then Mapessek-pessek stage to find detailed information about the bride and groom characters, Mammanuk-manuk stage is to send an envoy (Madduta Mallino) from the groom to meet the parents' bride to ask about the bride willingness to get married, Madduta Mallino stage which is sending envoys representing the prospective bridegroom's family to propose bride candidates, and Mappasiarekkeng stage, an agreement to determine Tanra Esso (D- day), Balanca (wife's spending money) / Doi Menre (spending money), Sompa (dower). The stages mentioned above are rarely performed, because Bugis realize that they do not live in their home region. So, the stages in marriage are more simple and flexible based on an agreement among the two prospective bride families (Interview with Maryam, March 4, 2019).

\section{Conclusions}

Sompe 'activities conducted by Bugis encouraged them to adapt on their new environments in the overseas, which are different from their original place. They are 
successful in adjusting to the natural, social, and cultural environments in Kemojan, Karimunjawa. The factors supporting the adaptation strategy by Bugis migrants are their philosophies related to local wisdom to create harmony in interacting with local community members. Cultural changing is adaptation strategies consequence faced by Bugis in Kemojan.

The inter-tribal marriage do not fade Bugis's culture, instead, it is adding the wealth of cultural treasures in Kemojan. Finally, the marriage between Bugis and Javanese, as well as other tribes does not eliminate one party language, they communicate use Buginese language, Javanese, Madurese and Indonesian to make their daily communication becomes vary.

\section{References}

[1]. Pelras, Christian: Manusia Bugis (terj.). Jakarta: NALAR bekerja sama dengan Forum JakartaParis. EFEO (2006).

[2]. Lineton, J. 1975 : "Pasompe' Ugi' : Bugis Migrants and Wanderers”, Archipel. Volume 10, pp. 173-201 (1975).

[3]. Aditjondro, George Junus : “Terlalu Bugis-Sentris, Kurang 'Perancis”, Makalah dalam Diskusi Buku Manusia Bugis di Bentara Budaya, Jakarta 16 Maret 2006.

[4]. Mude, M. Saleh., Malla Andang B., Atma, Asbar., Nawawi,Abdul Muid., Hartono, Rudi : Bugis di Tanah Rantau: Membangun Bangsa dan Negara, Merekat Etnis Nusantara. Jakarta: Penerbit FOCUS Grahamedia bekerja sama dengan BPP Kerukunan Keluarga Sulawesi Selatan.KKSS. (2009).

[5]. Harianto, Andi: http://sosbud.kompasiana.com/2010/08/21/ nyanyianrindu-perantau-bugis-danbekal-tellu-cappa/ ( diakses22 Juni 2019).

[6]. Moleong, Lexy J: Metode Penelitian Kualitatif. Bandung: Remaja Rosdakarya (2000)

[7]. Santana, Septiawan K : Menulis Ilmiah Metodologi Penelitian Kualitatif. Jakarta: Yayasan Pustaka Obor Indonesia ( 2010)

[8]. Endraswara, Suwardi: Metodologi Penelitian Kebudayaan. Yogyakarta: Gadjah Mada University Press (2003)

[9]. Kesuma, Andi Ida. Migrasi dan Orang Bugis. Yogyakarta, Penerbit Ombak (2004).

[10]. Suliyati, Titiek: Etnis Bugis Di Kepulauan Karimunjawa: Harmoni Dalam Pelestarian Budaya Dan Tradisi, dalam Jurnal Sabda Volume 11 (2016)

[11].http://ace-informasibudaya.blogspot.com, diunduh 1 Mei 2019

[12].Abdullah, Hamid : Manusia Bugis Makassar, Suatu Tinjauan Historis Terhadap Pola Tingkah Laku dan Pandangan Hidup Manusia Bugis Makassar. Jakarta: Inti Idayu Press ( 1985)

[13].Kaplan, David dan Manners, Albert A: Teori Budaya. Yogyakarta: Pustaka Pelajar (1999)

[14].Ma'asy, M. R.: Komunikasi Antar Budaya Perantau Bugis Dengan Etnis Kutai Di Samarinda Seberang. Journal Ilmu Komunikasi, 3(4), 282-295 (2015).

\section{Informants:}

$\begin{array}{ll}\text { No. } & \text { Name } \\ 1 & \text { Abbas } \\ 2 & \text { Abdullah } \\ 3 & \text { Dupadu } \\ 4 & \text { Fatima } \\ 5 & \text { Rosma } \\ 6 & \text { Rusingi } \\ 7 & \text { Sakim }\end{array}$

Sakim
Address
Kemojan village
Kemojan village
Kemojan village
Kemojan village
Kemojan village
Kemojan village
Kemojan village

\author{
Occupation \\ Fisherman \\ Entrepreneur \\ Trader \\ - \\ Fish seller \\ Fisherman
}

